\title{
Legal Protection on the Moral Rights and Economic Rights of the Author of Film Script Writing Pursuant to Law No. 28 of 2014 Concerning Copyright (Analysis of Copyright Infringement Case by a Production House of the "Benyamin Biang Kerok" Film)
}

\author{
Asima Trismawati Situmeang ${ }^{1}$, Saidin $^{2}$, T. Keizerina Devi A ${ }^{2}$ \\ ${ }^{1,2,3}$ Universitas Sumatera Utara, Indonesia \\ Corresponding Author: Asima Trismawati Situmeang
}

\begin{abstract}
Moral Rights and Economic Rights are Exclusive Rights that cannot be separated in relation to Copyrights. Copyright protects all forms of work, one of which is Film Script Writing as referred to in Article 40 paragraph (1) of Law Number 28 of 2014 concerning Copyright (UUHC). One of the forms of infringement on the copyrighted work of the film script is the reuse of the film script without the permission of the creator, resulting in the loss of the moral rights and economic rights of the creator. The problems in this study are: how to use the principles of Moral Rights and Economic Rights of the Author in claiming protection against Copyright infringement on Film Script Writing, how legal remedies can be taken in the form of legal protection for the Author of Film Script Writing used without permission, and how analysis of the Judge's decision on the violation of Moral Rights for the Creator in the dispute of the film "Benyamin Biang Kerok" based on the decision of the Panel of Judges Number 09/Pdt.Sus-HKI/Cipta/ 2018/PN Niaga Jkt. Pst. This research is descriptive analytical with a normative juridical approach. Qualitative analysis methods are used to process and analyze research data and then draw conclusions using deductive methods through a normative framework. The results of the research show: the use of the Principles of Moral Rights and Economic Rights of the Creator as a claim for infringement of Copyright
\end{abstract}

is listed in Article 4, Article 5. This right will continue to exist and is eternally attached to the Creator and will continue to apply indefinitely. Legal efforts as a form of legal protection for Film Scripts that are used without permission are to follow the provisions in Article 95 to Article 109 of the UUHC, namely by preventing violations from occurring and through alternative dispute resolution through arbitration or through the Commercial Court. The Plaintiff's lawsuit was declared defeated by the Panel of Judges, due to lack of parties. But the production of the film "Benyamin Biang Kerok" is not determined as a violation of the exclusive rights of the Creator. This decision has not provided justice and provided legal protection for the Plaintiff as the author of the original manuscript and it is feared that the same violation will continue to occur in the future. Suggestions that can be given include: in providing explanations and strengthening the importance of the Creator's Exclusive Rights, it is necessary to have awareness, socialization and public education so as not to use other people's creations carelessly. Legal efforts to prevent infringement of film script writing are to conduct socialization in the film industry and other related creative industries. Against a decision that has not provided legal protection for the Plaintiff, the Panel of Judges must also determine that the defendant has violated the exclusive rights of the Plaintiff's written film script and stipulates compensation for the violation of exclusive rights committed. 
Asima Trismawati Situmeang et.al. Legal protection on the moral rights and economic rights of the author of film script writing pursuant to law no. 28 of 2014 concerning copyright (analysis of copyright infringement case by a production house of the "Benyamin Biang Kerok" Film).

Keywords: Legal Protection, Moral Rights, Economic Rights, The Author, Copyrights, Film Script Writing.

\section{INTRODUCTION}

Intellectual Property Rights are material rights, rights to something that comes from the work of the brain, the work of ratios. The result of the work of reasoning human ratio. That on the one hand, on the other hand there is also the result of emotional labor. The work of the heart in an abstract form known as a blend of rational and emotional work gives birth to a work called intellectual work. According to Article 1 paragraph (1) of Law Number 28 of 2014 concerning Copyright (UUHC), what is meant by Copyright is the exclusive right of the creator that arises automatically based on declarative principles after a work is realized in a tangible form without reducing restrictions in accordance with the provisions laws and regulations. Copyright can also be interpreted as an exclusive right for the creator or recipient of the right to publish or reproduce his creation or give permission for it without reducing the restrictions according to the applicable laws and regulations, economy. Article 8 UUHC states that economic rights are the exclusive rights of the creator or copyright holder to obtain economic benefits from the creation. Meanwhile, moral rights in the terminology of the Bern Convention use the term moral rights, namely the rights attached to the creator. Attached means that the right cannot be deleted even though the copyright has expired within the term of ownership. Moral rights are distinguished from economic rights. If economic rights contain economic value, then moral rights have absolutely no economic value. The word "moral" shows the rights that are hidden behind the economic value. However, there are times when the value of moral rights actually affects the economic value. Article 5 paragraph (1) UUHC states that moral rights are rights that are eternally attached to the creator to:

a. Continue to include or not include his/her name on the copy in connection with the public use of his/her creation;

b. Using his real name or pseudonym;

c. Changing his creation in accordance with the propriety in society;

d. Change the title and sub-title of the creation; and

e. Defend his rights in the event of a distortion of the work, mutilation of the work, modification of the work, or anything that is detrimental to his honor or reputation.

Copyright protects all forms of works in the form of science, art, and literature, one of which is Film Script Writing. Article 40 paragraph (1) UUHC states that: Protected works include works in the fields of science, art, and literature, consisting of:

\section{a. Books, pamphlets, presentations of published works, and all other written works.}

Film Script Writing is included as one of the works of art in Intellectual Property, namely writings. Film Script Writing that is created by the Creator must be given protection so that unwanted things don't happen in the future, considering that making a Film Script Writing requires time, hard work, and ideas that are combined well to produce a good work of art. .One of the cases of copyright infringement on film scripts was between Syamsul Fuad (Plaintiff) against PT. Falcon Pictures, PT. Max Pictures, HB Naveen, and Ody Mulya Hidayat, hereinafter referred to as the Defendants, who have been ruled by the Central Jakarta Commercial Court with decision number 09/Pdt.Sus-HKI/Cipta/ 2018/PN Niaga Jkt. Pst. The Defendants produced the film "Benyamin Biang Kerok" which was released without the permission and knowledge of the Plaintiff as the original writer and creator of the film script "Benyamin Biang Kerok" and "Biang Kerok Untung" which was first released in 1972 and 1973, so that the Plaintiff felt the 
Asima Trismawati Situmeang et.al. Legal protection on the moral rights and economic rights of the author of film script writing pursuant to law no. 28 of 2014 concerning copyright (analysis of copyright infringement case by a production house of the "Benyamin Biang Kerok" Film).

right exclusive rights, namely Moral Rights and Economic Rights were violated by the Defendant. However, the Panel of Judges who examined and tried this case stated that the Plaintiff's claim could not be accepted due to lack of parties or the wrong address, thus rejecting all of the Plaintiff's claims in their entirety.

This research is important to be carried out for the following reasons, namely to analyze how the principles of Moral Rights and Economic Rights of the Creator are used as claims to protect against copyright infringement on Film Scripts, to analyze how legal remedies can be taken as a form of legal protection. the creator of the Film Script that is used without permission, and analyzes the judge's decision on the violation of the moral rights of the creator in the dispute for the film "Benyamin Biang Kerok" based on the decision of the Panel of Judges Number 09/Pdt.Sus-HKI/Cipta/2018/PN Niaga Jkt. Pst. So based on the description above, it is necessary to conduct further research on "Legal Protection of Moral Rights and Economic Rights of Writers of Film Scripts according to Law Number 28 of 2014 concerning Copyright (Analysis of Cases of Copyright Infringement by the Benyamin Biang Kerok Film Production House)".

\section{MATERIALS \& METHODS}

This research is descriptive analysis. Descriptive means being able to provide a clear and systematic description of the problem to be studied. Analysis means carefully analyzing problems based on pictures and facts so as to be able to answer problems related to this research, and by taking a normative juridical approach consisting of research on legal identification and research on legal effectiveness by researching literature or document studies carried out or aimed at only on written regulations or other legal materials and includes research on legal principles. obtained from: a. Primary legal materials, namely binding legal materials, namely in the form of legal regulations and legislation, and decisions include:

1) Civil Code (Burgerlijk Wetboek);

2) Law Number 19 of 2002 concerning Copyright in conjunction with Law Number 28 of 2014 concerning Copyright;

3) Central Jakarta Commercial Court Number 09/Pdt.Sus-HKI/Cipta/2018/PN Niaga Jkt. Pst;

4) Court Decisions and Jurisprudence related to the violation of Moral Rights on film copyrights.

b. Secondary Legal Materials, which provide an explanation of primary legal materials and can assist and analyze. This legal material consists of literature related to this thesis as well as discussing the issue of legal protection of moral rights, legal protection of copyrights, and those relevant to this research.

c. Tertiary Legal Materials, namely legal materials that provide explanations of primary legal materials and secondary legal materials, consisting of scientific journals, related theses, expert opinions, encyclopedias, Legal Dictionary, General Indonesian Dictionary, and so on.

\section{RESULT AND DISCUSSION \\ Use of the Principles of Moral Rights and Economic Rights of Authors as Claims for Protection Against Copyright Infringement on Film Script Writing.}

Protection of Intellectual Property Rights aims to protect copyright and to support and reward creativity. This protection is given in order to grow new innovations in the fields of industry as well as arts and sciences. The protection of intellectual property rights is also a valuable asset because it provides great economic rights. The existence of intellectual property rights can even become a catalyst for a country's economic growth. Because of its universal nature, the 
Asima Trismawati Situmeang et.al. Legal protection on the moral rights and economic rights of the author of film script writing pursuant to law no. 28 of 2014 concerning copyright (analysis of copyright infringement case by a production house of the "Benyamin Biang Kerok" Film).

protection of intellectual property rights must be supported and recognized by countries in the world. Protection of Moral Rights and Economic Rights is regulated in Article 4 UUHC where Copyright is an exclusive right consisting of Moral Rights and Economic Rights. Written works on film scripts are included in Copyright which is protected under Article 40 paragraph (1) UUHC.

Protection of Economic Rights that can be granted to the Author or Copyright Holder is stated in Article 9 paragraph (2) and paragraph (3), namely that everyone who uses Economic Rights as referred to in Article 9 paragraph (1) must obtain permission from the Author or Holder. Copyright and is prohibited from duplicating and using commercially without the permission of the Author. Article 9 paragraph (1) of the UUHC states that the Creator or Copyright Holder has the Economic Right to publish, reproduce, translate, adapt, distribute, perform, announce, communicate, and rent out. This means that if the above occurs without the permission of the Creator or Copyright Holder, then it is already a Copyright violation as referred to in Article 113 paragraphs (1), (2), and (3) of the UUHC.

The use of the principle of Moral Rights in the case of Copyright of the written work of the film script, the name of the creator or original author of the film script must absolutely be included in the credit title, but not always the inclusion of that name is made possible by the nature or form of the creation itself. This refers to the doctrine of the Moral Rights of the Creator which is commonly found in countries that follow the European civil law tradition, and American Copyright culture, and countries that follow the British customary law tradition. In European Copyright culture, the Creator becomes the center point who gets full rights in controlling every use of his work that may be detrimental to his interests. O.K. Saidin explained that in various European countries the regulations that protect literary and artistic works are not called or called "Copyright" laws, but the "Creator's Rights" or droit d'aueur laws in France, Urbeberrecht in Germany, and droit d'aueur in France. 'autore in Italy.

In the case of copyright infringement on the scripted works of Benyamin Biang Kerok and Biang Kerok Untung, that the Plaintiff is the author and creator of the original film script for the two films, then Moral Rights and Economic Rights are automatically attached to him as referred to in Article 4 UUHC.

The judge's consideration is based on the concept of recognizing the rights that are entitled to be obtained by the Creator (Hasibuan, 2008), namely:

a. The Right of Publication; the right to decide whether the work is to be made public. This means that only the Creator has the right to determine in what form and where his work will be published;

b. The Right of Paternity; the right of the author to safeguard his reputation by preserving the integrity of the work. Namely rights relating to the publication of a creation or work, which can be further divided into 3 (three) rights, namely the right to demand that the name of the Creator be imprinted on the reproduction of the work forever, the right to prevent others from calling themselves the Author, and the right to prevent the use of the work. as well as the inclusion of his name in the work of others;

c. The Right of Integrity; namely the right of the Creator to change his work and prohibit others from modifying his work or in other words the right to prevent distortion of the creation of the Creator's copyrighted work by others.

Reviewing the Plaintiff as the holder of Moral Rights and Economic Rights, his name has actually been included in the two films as a form of appreciation for his work as a story writer for the two films by the Defendant. In Article 57 paragraph (1) UUHC it is stated that the period of protection of Moral Rights in relation to Attribution Rights, such as the inclusion of 
Asima Trismawati Situmeang et.al. Legal protection on the moral rights and economic rights of the author of film script writing pursuant to law no. 28 of 2014 concerning copyright (analysis of copyright infringement case by a production house of the "Benyamin Biang Kerok" Film).

names or disguises on the work, defending its rights in the event of distortion of the work, mutilation of the work, or other things that harm its reputation is valid indefinitely. In the case of Moral Rights relating to the Right of Integrity, such as changing the work in accordance with the values of propriety in society or in the case of changing the title, it is valid for a period of time. Based on this Article and supplemented by Article 4 paragraph (2) UUHC concerning Moral Rights which are inherent in the Creator and cannot be transferred, the protection of the Moral Rights of the Plaintiff's copyrighted works must be provided.

Against the violation of Moral Rights and Economic Rights by the Defendant, even though the Copyright of the film script has been transferred either partially or completely to another party, it still does not reduce the rights of the Creator or his heirs to sue any person who intentionally and without rights and without the consent of the Author commits a crime. actions that can violate the Creator's Moral Rights. In a philosophical study, in terms of the economic rights of the Creator to his creation, the copyright has been transferred, but the moral rights to his creation still need to be protected.

In the claim of protection of exclusive rights to the copyright of written film scripts, it is in line with the principles of Intellectual Property (Ardin, 2016), including:

a. The Principle of Justice (The Natural Justice Principle), namely the law provides protection to the Creator on the basis of the power to act in the context of interests called rights. The creator in producing a copyrighted work is based on his intellectual ability, so it is a natural thing if the result of his work is given recognition

b. Economic Principles, namely intellectual property has economic value and is useful for human life. The economic value of Intellectual Property is also a form of wealth for the owner.
The creator benefits from ownership of his work, for example in the form of royalty payments, and so on.

c. The Cultural Principle, namely the acknowledgment of the creation of literary works from human creations which are expected to arouse enthusiasm and interest for others in giving birth to new creations for the growth of the development of science, art, and literature to improve the standard of life, dignity, and human civilization and also provide benefits to the nation and the State

d. The Social Principle, namely the Intellectual Property system can provide protection to the Creator not only in terms of fulfilling the interests of individuals and society. The form of this balance can be seen in the provisions of social functions and mandatory licenses in UUHC.

\section{Legal Efforts That Can Be Done As a Form of Legal Protection for Authors of Film Scripts that are Used Without Permission.}

Disputes over Copyright are disputes over assets, which in Copyright terminology are referred to as economic rights or economic rights. The disputes do not only stem from the existence of unlawful acts that cause harm to the Author or recipient of rights committed by other parties, or to acts of default as a result of violating the clauses contained in the license agreement. The two forms of legal action are generally regulated in Book III of the Civil Code, namely acts that are categorized as:

1. Onrechmatigdaad; and

2. Default.

In terms of compensation for copyright crimes, it also arises because of acts against the law, not because of default. There are 2 (two) elements of an unlawful act that must first be met before filing a claim for compensation, namely:

1. There are people who make mistakes;

2. The mistake causes the other person to suffer a loss. 
Asima Trismawati Situmeang et.al. Legal protection on the moral rights and economic rights of the author of film script writing pursuant to law no. 28 of 2014 concerning copyright (analysis of copyright infringement case by a production house of the "Benyamin Biang Kerok" Film).

If these two elements have been met, then an event can then be submitted to the court for compensation. The claim for compensation can be filed at the same time as a criminal charge, but because of the element of an unlawful act which first determines that there must be an error, whether intentional or due to negligence, it is better for the claim for compensation to be filed after there is a criminal decision that has permanent legal force as stated in the law has been included in Article 96 UUHC.

This Copyright Law states that the settlement of civil disputes regarding Copyright can be resolved in accordance with the judicial principles adopted by the civil justice system in Indonesia, namely quickly, cheaply, and at low cost. This is intended because this law places in the first place an alternative dispute resolution, the second is a settlement through arbitration, and in the third order is a dispute resolution through the courts. In the case of settlement of civil disputes, the court authorized to adjudicate is the Commercial Court as stated in Article 95 paragraph (2) UUHC. Other courts outside the Commercial Court are not authorized to handle Copyright dispute resolution. Even dispute resolution through mediation before carrying out criminal charges must still be carried out as long as the parties to the dispute are known to be in the territory of the Unitary Republic of Indonesia.

In legal protection for the Creator, Copyright Holder and/or Related Rights Holders or their heirs who have suffered economic rights losses, are entitled to get compensation for copyright infringement, in which the compensation is given and included at the same time in the court's decision regarding criminal cases. Copyright and/or Related Rights. Payment of compensation to the Author, Copyright Holder, and/or Related Rights Owner is paid no later than 6 (six) months after a court decision that has permanent legal force. Losses suffered by the Creator or his heirs or by the Copyright Holder and related rights do not have to be carried out through a civil lawsuit, but can also be included in the verdict in a criminal case.

In the event that the work has been registered in the General Register of Works and the letter has been issued by the Minister, the interested party may file a lawsuit for the cancellation of the Copyright registration in the general register of works through the Commercial Court addressed to the Author and/or Copyright Holder against. This is a consequence of the Copyright registration system which adheres to a negative-declarative registration system.

Although previously there has been a transfer of economic rights to the Performer by another person intentionally and without rights, it will not reduce the right of the Performer or his heirs to file a lawsuit in the event that there has been a violation of the Moral Rights of the Performer as referred to in Article 5 paragraph (1).

For copyright infringement committed by a third party, the subject who is entitled to file a claim for compensation to the Commercial Court is the Creator, Copyright Holder or Related Rights Owner. The claim for compensation can be in the form of a request to surrender all or part of the income obtained from holding lectures, scientific meetings, performances or exhibitions of works that are the result of infringement of Copyright or Related Rights Owners. In addition to filing a lawsuit, the Author, Copyright Holder, or Related Rights Owner may request a provincial decision or an interim decision to the Commercial Court to:

1. Request the confiscation of the work that has been announced or reproduced, and/or the Reproduction tool used to produce the copyright infringing work and Related Rights products; and/or.

2. Stop the activities of Announcement, Distribution, Communication, and/or Reproduction of works which are the result of infringement of Copyright and Related Rights products. 
Asima Trismawati Situmeang et.al. Legal protection on the moral rights and economic rights of the author of film script writing pursuant to law no. 28 of 2014 concerning copyright (analysis of copyright infringement case by a production house of the "Benyamin Biang Kerok" Film).

A. Legal Analysis of Decision Number 09/Pdt.Sus-HKI/Cipta/2018/PN Jkt.Pst.

1. The Case of the Violation of the Author's Moral Rights Position in the Dispute of the Film "Benyamin Biang Kerok"

Decision Number 09/Pdt.Sus-

HKI/Cipta/2018/PN Niaga Jkt.pst is regarding the dispute between SYAMSUL FUAD (hereinafter referred to as the Plaintiff) against PT. FALCON or Falcon Pictures (Defendant 1), PT. MAX KREATIF INTERNATIONAL or Max Picture (Defendant 2), NIRMAL HIROO BHARWANI alias HB NAVEEN (Defendant 3), and ODY MULYA HIDAYAT (Defendant 4).

The Defendants produced the film "Benyamin Biang Kerok" which was released without the permission and knowledge of the Plaintiff as the original writer and creator of the film script "Benyamin Biang Kerok" and "Biang Kerok Untung" which was first released in 1972 and 1973, so that the Plaintiff felt the right exclusive rights, namely Moral Rights and Economic Rights were violated by the Defendant. The Plaintiff was disappointed in the making of the film because the Plaintiff's moral and economic rights were violated in the filming process by the Defendants. However, the Panel of Judges who examined and tried this case stated that the Plaintiff's claim could not be accepted due to lack of parties or the wrong address, thus rejecting all of the Plaintiff's claims in their entirety.

\section{B. Legal Analysis of Decision Number 09/Pdt.Sus-HKI/Cipta/2018/PN Jkt.Pst.}

Syamsul Fuad as the Creator who holds the rights to the original film script of the film "Benyamin Biang Kerok" and its sequel, "Biang Kerok Lucky", automatically also attaches his exclusive rights, namely Moral Rights and Economic Rights to the works he creates. For this achievement, he gets a moral advantage in the form of keeping his name included in the film, regardless of the economic benefits and still holding the Copyright until now without having to transfer the ownership of the Copyright to the Film Script.

The license agreement made between Falcon Pictures and the Benjamin Suaeb Foundation is actually not needed in the remake of the BBK film, because the film is not a biopic or biographical film about Benjamin Suaeb's life journey, but a comedy genre film that tells the story of Pengki's shop as Biang Kerok. Benjamin Suaeb only plays the main role as Pengki, while Syamsul Fuad still holds the copyright for the film legally and fully.

In the films "Benyamin Biang Kerok" and "Biang Kerok Untung" which were produced by Falcon Pictures in 2018, there are several similarities with the BBK film created by Syamsul Fuad, including:

1. Similarity to the title of the film;

2. Similarities to the main fictional character, namely Pengki, in the form of a name, character/character, where Pengki has a distinctive voice and laughing style that is still attached to Indonesian society today;

3. The similarity as a musical film, shown by the main character Pengki, who occasionally sings and dances with other characters, especially his female partner, by singing the typical songs that Pengki has performed in the 1972 film BBK;

4. The similarity of showing the sequel (continued story) of the film. The BBK film produced by Falcon Pictures was aired on March 1, 2018, which was then followed by a sequel with the title "Biang Kerok Untung" which is scheduled to air in December 2018, where the story is still related to the previous film. This clearly imitates the success of the sequel to the film BBK in 1972 and and was followed by the success of Biang Kerok Untung in 1973.

Syamsul Fuad through his attorney stated that until now the rights to the stories of the films "Benyamin Biang Kerok" and "Biang Kerok Untung" have never been transferred by the Plaintiff to any party, where it is clear that the stories for the two 
Asima Trismawati Situmeang et.al. Legal protection on the moral rights and economic rights of the author of film script writing pursuant to law no. 28 of 2014 concerning copyright (analysis of copyright infringement case by a production house of the "Benyamin Biang Kerok" Film).

films are the original creations of the Plaintiffs. in the field of art and literature produced through inspiration, ability, imagination, thought, skill, dexterity or expertise expressed in a tangible form.

Meanwhile, Falcon Pictures and Max Pictures' claims for ownership of the rights to the $\mathrm{BBK}$ film do not necessarily allow third parties to freely use or modify, or change the stories contained in them because the stories have their own Copyright and are protected by UUHC as the result of copyrighted works in Indonesia. arts and literature. The absence of the Plaintiff's name as the original author of the film's story on the credit title, film recordings, published film posters, as well as news and books related to the 2018 film "Benyamin Biang Kerok" has proven that a third party has consciously used it. Plaintiff's story intentionally and without rights.

Films that remake, adapt, or are inspired by a work (usually a literary work) will include the phrase "inspired by" or "based on" in the credit title and film poster. Therefore, for this type of film, the film producer must first obtain the Copyright for the film so as not to violate the Copyright of the author of the original Film Script. (Yunarti, 2017)

Film Manuscripts Films as derivative creations created through adaptation, transformation, translation or arrangement in which have a Copyright. Even in this case, the copyright owner of the derivative work with the copyright owner of the original work still has the same rights in terms of distribution of royalties.

The films "Benyamin Biang Kerok" and "Biang Kerok Untung" are not derivative works because these films are works of fiction in the form of essays originating from the ideas, imagination and creativity of Syamsul Fuad as the original writer of the story film script. It is clear that the BBK film is not a biopic about the life story of Benjamin Suaeb that can be turned into a story, and Falcon Pictures as the party adapting the original film script must obtain prior permission from Syamsul Fuad as the Copyright Holder for the film "Benyamin Biang Kerok" and "Biang Kerok Untung" before the 2018 remake of the film.

The use of copyrighted works belonging to the Author by other parties must take into account the exclusive rights of the Author, namely Moral Rights and Economic Rights, so that in the future there will be no violations of these rights or other related rights. A Creator has the Moral Right to obtain protection for his copyrighted work in the form of attachment (right of attribution), in other words a creation is a unity that cannot be separated from its Creator. Therefore, the name of the Creator must always be attached to his creation (doctrine of paternity), and must not be changed without the approval of the Creator (doctrine of integrity). Against the violation of Moral Rights committed by Falcon Pictures, in the process of remake or remake the films "Benyamin Biang Kerok" and "Biang Kerok Lucky" it should have obtained permission from the Creator or Copyright Holder first, as stated in Article 9 paragraph (2) UUHC, that is, any person without permission from the Author or Copyright Holder is prohibited from duplicating and/or commercially using the work.

\section{CONCLUSION}

Based on the descriptions that have been described in previous chapters, the following conclusions can be drawn from the results of this study:

1. The use of the Principles of Moral Rights and Economic Rights of the Author as a claim for infringement of Copyright is stated in Article 4, Article 5, and Article 9 of Law Number 28 of 2014 concerning Copyright. The consequences of Moral Rights and Economic Rights that continue to exist and are eternally attached to the Creator cause the Moral Rights to continue in effect indefinitely, except for changes to a creation that are adapted to the needs of the community. 
Asima Trismawati Situmeang et.al. Legal protection on the moral rights and economic rights of the author of film script writing pursuant to law no. 28 of 2014 concerning copyright (analysis of copyright infringement case by a production house of the "Benyamin Biang Kerok" Film).

2. Legal remedies that can be taken as a form of legal protection for the Author of the Written Script of Film used without permission is to be able to follow the provisions in Article 95 to Article 109 of Law Number 28 of 2014 concerning Copyright. Legal protection in this case includes preventive legal protection (for prevention), namely by preventing violations from occurring and repressively (pressing) through alternative dispute resolution through arbitration or through the Commercial Court.

3. Against the Plaintiff's claim which was declared defeated in Decision Number 09/Pdt.Sus-HKI/Cipta/2018/PN Jkt.Pst, the Panel of Judges decided that the Plaintiff's claim was lacking and declared unacceptable and the Panel of Judges decided not to grant all of the Plaintiff's claims. . However, the production of the film "Benyamin Biang Kerok" and its sequel, "Biang Kerok Untung" which was produced by Falcon Pictures without permission, changed the original script, and the omission of the original author's name is not determined as a violation of the exclusive rights of the Creator, relating to Moral Rights and Economic Rights as stated in Article 5 of Law Number 28 of 2014 concerning Copyright. This decision has not provided justice and provided legal protection for the Plaintiff as the author of the original manuscript and it is feared that the same violation will continue to occur in the future.

Acknowledgement: None

Conflict of Interest: None

\section{Source of Funding: None}

\section{REFERENCES}

1. Fajrin Falakhi Ardin, Tinjauan Yuridis HakHak Pengarang dalam Penerbitan Buku Berdasarkan Undang-Undang No. 28 Tahun 2014 tentang Hak Cipta (Studi Kasus Surat Perjanjian Penerbitan No. 02/AILEGAL/II/2018 di CV. Aneka Ilmu Kabupaten Demak), Skripsi, Universitas Negeri Semarang, Semarang, 2016, hlm. 1617.

2. Mazaya, Ranti Fauza. 2004. Pelindungan Desain Industri di Indonesia. Jakarta: Grasindo.

3. Otto Hasibuan, Hak Cipta di Indonesia, PT. Alumni, Bandung, 2008, hlm. 70.

4. Saidin, O.K. 2015. Aspek Hukum Hak Kekayaan Intelektual (Intellectual Property Rights) cet. VIII. Jakarta: PT. Raja Grafindo Persada.

5. Thomas, Meldy Rivan 2021. Masa Berlaku Hak Ekonomi Pencipta Atau Pemegang Hak Cipta Menurut Undang-Undang Nomor 28 Tahun 2014 Tentang Hak Cipta, Jurnal Lex Privatum Vol. IX No. 1, Januari-Maret 2021.

6. Yunarti, Aditya. 2017. Analisis Kepemilikan Hak Cipta Atas Film Tokoh Nasional: Studi Kasus Putusan Mahkamah Agung Nomor 305 K/Pdt.Sus-HKI/2014 tanggal 19 Agustus 2014 antara Rachmawati Soekarnoputri melawan PT. Tripar Multivision Plus, dkk. Tesis. Yogyakarta: Universitas Gadjah Mada.

How to cite this article: Situmeang AT, Saidin, T. Keizerina Devi A. Legal protection on the moral rights and economic rights of the author of film script writing pursuant to law no. 28 of 2014 concerning copyright (analysis of copyright infringement case by a production house of the "Benyamin Biang Kerok" Film). International Journal of Research and Review. 2021; 8(8): 731-739. DOI: https://doi.org/10. 52403/ijrr.20210896 